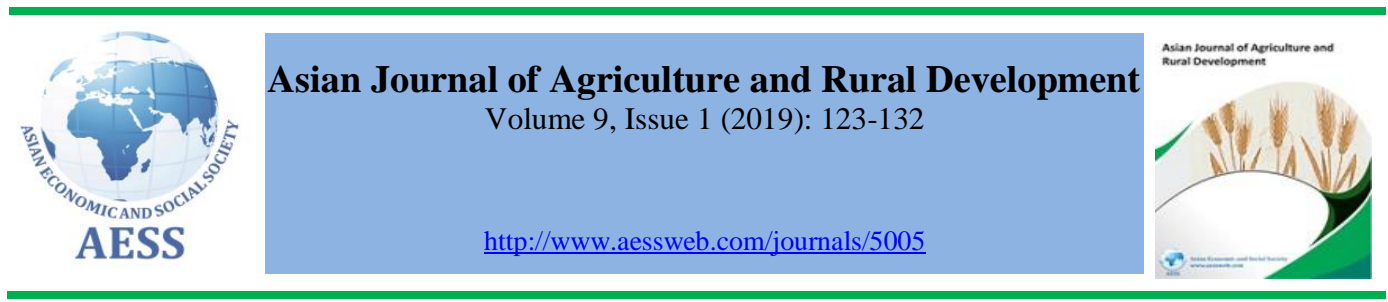

\title{
ANALYSIS OF BANANA PRODUCTION PRACTICES AND CONSTRAINTS IN EMBU COUNTY, KENYA
}

Arphaxard Ireri Muthee , Department of Agricultural Resource Management, University of Bernard Mukiri Gichimu,

Paul Njiruh Nthakanio $\bowtie$ patrickireri66@gmail.com (Corresponding author)

\begin{tabular}{|c|c|}
\hline ARTICLE HISTORY: & ABSTRACT \\
\hline $\begin{array}{l}\text { Received: } 27-\text { Mar-2019 } \\
\text { Accepted: } 07-J u n-2019 \\
\text { Online Available: } 24-J u n- \\
2019\end{array}$ & $\begin{array}{l}\text { This study was carried out to determine banana production } \\
\text { constraints in Embu County in order to seal this production gap. A } \\
\text { survey was conducted in the four sub-counties in Embu County } \\
\text { namely, Runyenjes, Manyatta, Mbeere North and Mbeere South, to } \\
\text { assess the production constraints limiting banana production. }\end{array}$ \\
\hline $\begin{array}{l}\text { Keywords: } \\
\text { Manyatta, } \\
\text { Mbeere North, } \\
\text { Mbeere South and } \\
\text { Runyenjes }\end{array}$ & $\begin{array}{l}\text { Respondents were smallholder banana farmers selected using } \\
\text { cluster sampling method from } 22 \text { farmers groups in the County. } \\
\text { The cluster sampling was based on a number of operational } \\
\text { irrigation schemes in each of the four sub-counties, and with at least } \\
15-30 \text { active members. The study established that banana } \\
\text { production in Embu County is highly constrained by poor } \\
\text { husbandry practices, pests and diseases, lack of clean planting } \\
\text { materials, and lack of adequate extension services. }\end{array}$ \\
\hline
\end{tabular}

\section{Contribution/ Originality}

This study is the first attempt to investigate the banana production constraints at the level of the farmer in Embu County since agriculture became a devolved function in Kenya. The study is therefore very timely and will help the County government to establish necessary mitigation measures and policies to address production constraints and the yield levels and economic livelihood of farmers.

DOI: 10.18488/journal.1005/2019.9.1/1005.1.123.132

ISSN (P): 2304-1455/ISSN (E):2224-4433

How to cite: Arphaxard Ireri Muthee, Bernard Mukiri Gichimu and Paul Njiruh Nthakanio (2019). Analysis of banana production practices and constraints in Embu County, Kenya. Asian Journal of Agriculture and Rural Development, 9(1), 123-132.

(C) 2019 Asian Economic and Social Society. All rights reserved. 


\section{INTRODUCTION}

The worldwide consumption of banana (Musa spp) as fruit is second after apple due to its high nutritional and medicinal value (Kirogo, 2006). It is a powerhouse of nutrients that maintain good health (Kirogo, 2006). It is rich in potassium, carbohydrates and vitamin A, providing over $25 \%$ of the carbohydrate requirements for more than 70 million people in the world (Njue, 2015). In Kenya, banana is a major food and cash crop that contributes significantly to the diets of many people, and the Gross Domestic Product (GDP) of the Kenyan economy (Kahangi, 2002; Nguthi, 2007). In most developing countries, banana is ranked as the fourth food crop after rice, wheat and maize, and is a principal source of employment as well as on-farm and off-farm income in its major production areas (Tumuhimbise and Talengera, 2018). However, banana production in Kenya is very low ranging from 4.5-10 tons/ha compared to the international levels of 40-50 tons/ha (Njue, 2015).

According to Kahangi (2002), low banana productivity in many parts of Kenya is attributed to socio-economic and technical factors. The socio-economic factors include lack of proper marketing and processing channels for banana production, inadequate government support, and poor infrastructure, high cost of farm inputs and poor organization of farmer cooperatives. These constraints subsequently enhance the cost of production. Inadequate market information and improper marketing and processing channels have exposed most of the farmers to middlemen who buy their farm produce at very low farm-gate prices, which sometimes do not break-even (Matere, 2009). Inadequate modern extension services for smallholder farmers have made it difficult to organize farmers into producer/marketing groups even among those who understand the benefits of such groups (Shiferaw et al., 2011). On the other hand, biotic and abiotic constraints coupled with inappropriate husbandry practices have added to the steady decline in banana yields in Kenya (Wachira et al., 2013). Husbandry practices may include soil fertility management practices and plant nutrition approaches, plant water relations and management, and inappropriate technologies in control and management of pests and diseases (Sanginga and Woomer, 2009; Wachira et al., 2013).

Agwara (2017) reported that Embu County produces $12 \%$ of all bananas produced in Kenya and is ranked third after Meru (19\%) and Kirinyaga (14\%). Other banana producing counties in Kenya are Taita Taveta (9\%), Muranga (7\%), Kisii $(6 \%)$, Tharaka Nithi $(6 \%)$ and Bungoma (5\%). According to the data from Embu County Department of Agriculture, Manyatta and Runyenjes sub-counties are leading in banana production in Embu County, producing approximately $50 \%$ and $43.8 \%$ of the total banana production in the County respectively. The remaining $6.3 \%$ comes from Mbeere North and Mbeere South sub-counties. However, the County has continually recorded declining banana yields in recent decades. Previous studies are generally concentrated in measuring banana yield levels without establishing the factors leading to low yields and necessary mitigating actions at the farmer level. There are therefore inadequate data on the causes of low banana yield in Embu County. This has made it difficult to develop programs to uplift the yield levels even at the policy level. This study was therefore aimed at determining the production constraints facing banana production in Embu County.

\section{MATERIALS AND METHODS}

\subsection{Description of the study area}

Embu County is situated in the eastern slopes of Mt. Kenya at an elevation between $700 \mathrm{~m}-1780$ $\mathrm{m}$ above sea level. The average annual rainfall is $1252 \mathrm{~mm}$ and is recorded in two distinct rainy seasons; the long rains (mid-March to September) with an average rainfall of $650 \mathrm{~mm}$ and the short rains (mid-October to February) with an average of $450 \mathrm{~mm}$ (Kenya Information Guide, 2015). The area has an average temperature of $19.5^{\circ} \mathrm{C}$ with a mean minimum of $14.1^{\circ} \mathrm{C}$, and a 
mean maximum of $25^{\circ} \mathrm{C}$ annually. The average annual evaporation potential is $1422 \mathrm{~mm}$, while the mean annual evapo-transpiration potential is $950 \mathrm{~mm}$ (Jaetzold et al., 2006). Soils are mainly hemic Nitosols, derived from basic volcanic rocks. They are deep, highly weathered with friable clay texture and moderate to high inherent fertility (FAO, 2011). Most farmers rely on the production of crops like maize, pulses, and horticultural crops such as tomatoes alongside rearing livestock. According to MoALF (2016), bananas in Embu County are mainly cultivated in the LH1, UM1, UM2 and UM3 agro-ecological zones (AEZs). Manyatta and Runyenjes sub-counties extend from cold and wet agro-ecological zone LH1 to warmer and humid AEZs UM1, UM2 and UM3. Mbeere North and Mbeere South sub-counties are found in LM3, LM4 and LM5 AEZs which are characterized by hot and dry semi-arid conditions and mainly engaged in indigenous livestock keeping and growing of drought-resistant crops such as millet, sorghum, cow peas and green grams (Jaetzold et al., 2006).

\subsection{Sampling and data collection techniques}

The survey was carried out using focused group discussion questionnaires, to ascertain banana production and marketing constraints in Embu County. Respondents were smallholder banana farmers drawn from Twenty-two groups in the four sub-counties in Embu County. Twenty-two groups were selected using cluster sampling methods based on a number of operational irrigation schemes in each of the four sub-counties, registered with the department of social services and with at least $15-30$ active members. The cluster groups were distributed in the four sub-counties of Embu County as follows; Runyenjes - 9, Manyatta - 10, Mbeere North - 1 and Mbeere South 2. In each sub-county, 15 farmers were interviewed from each group. The data collected was organized and analyzed using the Statistical Package for Social Sciences (SPSS). The results were summarized using descriptive statistics, graphs and pie charts and used to draw conclusions and to make recommendations on the best intervention to promote banana productivity in the County.

\section{RESULTS AND DISCUSSION}

\subsection{Banana varieties and their economic importance}

This study found that the main purpose of banana production in Embu County is for commercial use. However, only $30 \%$ of the farmers had a well-managed banana orchard, producing the anticipated three bunches per stool per year. A Similar observation was made in neighboring counties of the Kirinyaga and Meru by Mbaka et al. (2008). The study established that, on average, farmers had 75 stools of improved varieties and 120 stools of traditional varieties. William Hybrids was rated the most popular improved variety in Embu County, with a preferential rate of $22 \%$, followed by Grand Nain (20\%) and Giant Cavendish (18\%). Kasyoka et al. (2010) attributed the high preference of Grand Nain in the County, to influence from NGOs and high incidence of the Fusarium wilt disease. Other improved varieties grown in the county included Kampala (10\%) and FHIA 17 (6\%). Other studies (Mbaka et al., 2008; Kasyoka et al., 2010) found the cultivar Kampala to be among the most preferred varieties in Muranga, Meru and Kirinyaga. The cultivar is reportedly high yielding, of good keeping quality (long shelf life) and good taste. Kiganda was rated the most popular local variety in Embu County with a preference rate of $14 \%$, followed by Muraru with a popularity of $10 \%$.

Mbaka et al. (2008) reported that farmers' choice of cultivar was mostly determined by its market demand, production suitability in the area, and the relative ease of crop management. Kasyoka et al. (2010) further attributed the choice of cultivar to local culture and exposure to new technologies through NGOs. This study did not explore the fate of bananas after sale, but all the farmers sold their bananas in unprocessed form either raw or ripened, without any value addition. This concurred with Ouma et al. (2010) who reported that, most bananas in Kenya are utilized either as a dessert or cooked, and some are subjected to dual purpose especially in central Kenya. 
Other secondary uses for banana products that were mentioned by the farmers included livestock feed, compost manure, mulching, rope/mat making and thatching.

\subsection{Banana Production Practices}

\subsubsection{Production systems}

This study established that only $17 \%$ of farmers practiced strictly pure stand production system, where bananas were planted in separate blocks from other crops. Another 17\% of the farmers practiced intercropping system, where bananas were mixed with other crops like beans, vegetables, sweet potatoes, fruit/nut trees and agroforestry trees. Majority of the respondents $(53.1 \%)$ practiced both pure stand and intercropping farming systems at a varying extent. Out of the $17 \%$ of the farmers who practiced pure stand production system, $40 \%$ maintained pure stands of improved varieties, while $60 \%$ mixed both improved and traditional varieties in the same block. Ouma (2009) reported that intercropping is a very common cropping system in East Africa, and it is practiced by most of the banana farmers mainly due to declining land sizes and food security needs. El-Showk (2007) also reported that bananas in Kenya were mainly grown by smallholder farmers, and are usually intercropped. Intercropping banana with other crops has been reported to have several benefits. For example, intercropping banana with millet and some legumes such as Canavalia muzinna and Tephrosia vogelli has been reported to lower the number of banana weevil (C. sordidus) without affecting banana yields (Ouma, 2009). Wachira et al. (2013) argued that, although intercropping has a secondary benefit to soil fertility improvement, it makes pests and disease management difficult and lowers the available nutrients for crop uptake due to the competition of limited soil nutrients and sunlight. Intercropping may also lower the yield of both crops although it ultimately increases the combined yields and hence the total income. Intercropping is also favored if one of the crops (e.g., maize or beans) is consumed and the other one (e.g. banana) is used as a cash crop, as it is the case in Embu County.

\subsubsection{Adoption of tissue culture planting materials}

Generally, there was low adoption of recommended production technologies among the sampled farmers. Only $27.8 \%$ of the sampled farmers embraced the use of tissue culture (TC) planting materials. This is a very low adoption rate, considering the benefits associated with TC technology which includes the production of pest and disease-free planting materials, and increased productivity (Wasala, 2014). Tissue culture plantlets are also more vigorous, are able to multiply faster and also lead to faster maturity (Muyanga, 2009). Low adoption of TC technology was also reported by Mbaka et al. (2008), Acharya and Mackey (2009), Indimuli (2013) and Wasala (2014). Mbaka et al. (2008) attributed the low adoption rate to the high cost of TC banana planting materials. Wasala (2014) recommended the provision of affordable TC plantlets to smallholder farmers, to reduce their reliance on the use of conventional suckers which are more prone to pest and disease attacks, and hence contribute to the decline in banana production. According to Muyanga (2009), adoption of TC technology increases farmer income, due to a reduction in the cost of controlling pests and diseases.

\subsubsection{Soil fertility management}

It was apparent that most farmers in Embu County were not aware of the importance of soil testing in Banana production. Most of the farmers who tested their soil in the last five years were from Runyenjes (40\%) followed by Manyatta (38\%). The practice was relatively less common in Mbeere North (12\%) and Mbeere South (10\%) sub-counties. However, most (90\%) of these farmers expressed the need for urgent training on soil testing and soil fertility management in banana production. Mugendi and Muriuki (2012) expressed the importance of soil and tissue analysis as the only way through which the nutritional status of both the soil and the plant could be precisely determined, and deficiencies effectively corrected during fertilizer applications. Fageria 
and Baliger (2008) and Pan et al. (2012) recommended that soil testing for pH, organic matter content, as well as available macro and micro nutrients can provide the information needed to evaluate the soil fertility status. Banana demands greater quantities of Nitrogen, Phosphorous, Potassium (Bhalerao et al., 2009), Calcium, Magnesium and Sulphur (Rajput et al., 2017) in addition to essential micronutrients such as Boron, Iron, Copper, Manganese and Zinc (Cordeiro and Borges, 2000).

This study identified lack of fertilizer application as one of the major constraints contributing to declining banana yields in Embu County since only $15 \%$ of the respondents were found to be applying manure and other fertilizers to their banana orchards. Mugwe et al. (2009) attributed the low per capita food production on smallholder farms of sub-Saharan Africa, to reduce soil fertility. Among the few farmers who applied fertilizers in their orchards, none of them adopted the use of bio-fertilizers. Use of chemical fertilizers alone has been reported to have a deleterious effect on soil physical, chemical and biological properties, which affected the crop productivity in the long run. Ganapathi and Dharmatti (2018) recommended the integration of both organic and inorganic sources of nutrients in order to achieve higher yields, and also to sustain the soil fertility status in the long run. A Similar recommendation was also issued by El-Showk (2007) and Mugwe et al. (2009). Farmers cited unavailability of manure and high cost of inorganic fertilizers as the major factors hindering their application. A similar concern was raised by small-scale banana farmers in India (Ganapathi and Dharmatti, 2018).

\subsubsection{Other agronomic practices}

There was also inadequate adoption of other agronomic practices among the farmers. A Similar observation of low adoption of recommended practices among banana farmers was made by Woniala and Nyombi (2014) in Uganda. Although the respondents were selected based on a number of operational irrigation schemes in each of the four sub-counties, only $13 \%$ and $12 \%$ of the respondents were found to be practicing irrigation and weeding to their orchards respectively. Failure to practice irrigation implies that moisture stress affects the yields. According to Nyombi (2013), bananas require $25 \mathrm{~mm}$ of rainfall per week for satisfactory growth, which corresponds to $1300 \mathrm{~mm}$ per year. In order to achieve good yields, bananas should consistently receive 200 to $220 \mathrm{~mm}$ of water per month (Infonet, 2016). The County's bi-modal rainfall pattern is thus less than the ideal for banana production. Failure to practice weeding in banana orchards may not only reduce yields but certain weed associated with banana are also known to harbor pests which cause major losses in production (Isaac et al., 2012).

Only $5 \%$ of the sampled farmers practiced deleafing, which is the hygienic removal of banana leaves that are infected with the black-leaf-streak disease (black sigatoka) (Chillet et al., 2013). However, even a few farmers who were reported of practicing deleafing, did not associate the practice with the management of this disease. This is an extensive gap that needs to be addressed. Deleafing does not only contribute to the management of black sigatoka disease, but also the cutting of leaves help in moisture conservation. On the other hand, less than $5 \%$ of the sampled farmers were reported of practicing other recommended practices such as pruning, mulching, pests and disease management, desuckering, mattacking, denavelling and bagging. Although the majority of farmers attributed this low adoption rate to lack of adequate extension services, some farmers reported that they were aware of these practices but they lacked the manpower to implement them. Wachira et al. (2013) also reported that some banana farmers in the Murang'a County demonstrated adequate awareness of recommended banana management practices but were reluctant to adopt them, due to high cost implications and lack of technical know-how. 


\subsection{Pest and Disease Prevalence}

\subsubsection{Common banana pests}

Several pests and diseases were found to pose serious problems to the banana growers. According to the sampled farmers, the major banana pests in Embu County are nematodes (26\%), banana weevil (26\%), banana thrips (24\%) and moles (21\%). This observation concurred with Wachira et al. (2013) who reported that nematodes, banana weevil and thrips are among the major pests limiting banana production in many growing regions in Kenya. Nematodes, particularly $R$. similis, damages the feeder roots of secondary and tertiary banana roots thus reducing the yields by more than 50\% and significantly reducing the productive life of banana fields (Isaac et al., 2012). Heavy nematode infestation may also cause severe necrosis and toppling of banana plants (Queneherve et al., 2006; Isaac et al., 2007). The banana weevil (Cosmopolites sordidus) is an important pest of bananas in all production regions in the Kenya with associated yield losses ranging from $40 \%$ to $100 \%$ (Wachira et al., 2013). This study further established that only $20 \%$ of farmers had adopted chemical pest control with majority of them applying traditional methods like application of ash to control nematodes. Banana thrips and moles were also recorded among the most common pests in the study area with an occurrence of $24 \%$ and $21 \%$ respectively. Wachira et al. (2013) also reported high incidence of thrips in Maragua sub-county of Murang'a County. The sampled farmers also mentioned other minor pests including squirrels, birds and bats which scratch and blemish banana fingers lowering the quality.

\subsubsection{Common banana diseases}

The sampled farmers identified four banana diseases as the most common in Embu County. These were cigar-end-rot (23\%), sigatoka (22\%), bunchy top (20\%) and Fusarium wilt or panama disease (19\%). According to the respondents, all banana varieties are prone to banana pests but their susceptibility to diseases varies according to cultivar and management practices. Unfortunately, some of the sampled farmers were not well conversant with requisite skills to identify the pests and diseases and therefore the actual importance of these diseases in the field should be confirmed.

The cigar end rot disease was the most common in the study area with $23 \%$ occurrence rating according to the sampled farmers. This was in contrast with the finding of Wachira et al. (2013) who reported low prevalence of cigar end rot disease in Maragua sub-county in Murang'a County. Sigatoka disease was rated the second most prevalent disease in the study area. Unfortunately, none of the farmers demonstrated knowledge of the occurrence of two types of sigatoka - the yellow sigatoka caused by the fungus Mycosphaerella musicola (Chillet et al., 2013) and the black Sigatoka caused by M. fijiensis Morelet (Marin et al., 2003). Likewise, none of the farmers demonstrated awareness that yield losses from sigatoka diseases can be strongly reduced by removal of necrotic leaves (Vargas et al., 2009; Chillet et al., 2013).

The bunchy top viral disease and panama disease (Fusarium wilt) also recorded a high occurrence rating in the study area of $20 \%$ and $19 \%$ respectively. Wachira et al. (2013) also reported the two diseases as important and widespread banana diseases in Maragua sub-county. Contradicting report from James (2011) indicated that Bunchy top disease is not present in East Africa but Niyongere et al. (2011) reported that it is the most catastrophic viral disease of banana and plantain in Africa, South-East Asia and Australia. The disease is vector transmitted by the aphid Pentalonia nigronervosa and is spread through infected planting materials (Hu et al., 2007). Fusarium wilt, commonly known as the Panama disease, is caused by Fusarium oxysporum, fs cubense (El-Showk, 2007). This disease has no cure and is thus considered one of the most disastrous diseases in the world. In susceptible cultivars, the disease spreads very rapidly causing pseudostem split and high level of fatality. Contamination occurs from infected soil, tools and water (El-Showk, 2007). Mwangi and Nakato (2007) reported that up to 100\% crop loss may occur in wilt infested fields. 
The sampled farmers also mentioned Anthracnose as a common post-harvest disease during ripening and at kiosks or market stalls. Similar observation was made by Wachira et al. (2013) in Maragua sub-county. According to the respondents, all banana varieties are prone to banana pests and diseases but vary in their susceptibility to the common diseases identified in Embu County.

\section{CONCLUSION AND RECOMMENDATIONS}

\subsection{Conclusion}

The study found that there is low adoption of recommended production technologies among the banana farmers in Embu County. Some important technologies that are yet to be well embraced by farmers in the County include the use of tissue culture planting materials, proper application of manure and fertilizers (both organic and inorganic) and control of pests and diseases. Even simple technologies such as irrigation, weeding, deleafing, pruning, mulching, desuckering, mattacking, denavelling and bagging showed very poor adoption. Low adoption of technologies was associated with lack of technical know-how among farmers due to lack of adequate modern extension services. However, some farmers were well aware of these practices, but they lacked the ability to implement them due to the high cost implications.

\subsection{Recommendations}

The study recommends the following measures for improved banana production in Embu County:

1. Adoption of recommended crop husbandry practices including soil fertility management techniques, pests and disease management, adequate water utilization and conservation measures, and the use of clean planting materials will effectively improve crop growth and yields of bananas. County and National Governments should support farmers with subsidized farm inputs, easy access of tissue culture bananas, and available irrigation water through piped systems, construction of dams, boreholes, and shallow wells or water pans for rainwater collection.

2. The role of extension officers in ensuring that the above recommendation is achieved cannot be overemphasized. Banana farmers need to be equipped with skills on the proper management of soil fertility, proper and timely identification of pests and diseases, and available prevention and control measures ranging from biological, chemical and cultural methods. National and County Governments should therefore, ensure adequate extension services are made available to the farmers. This can be easily achieved if farmers are organized into groups.

\footnotetext{
Funding: This study received no specific financial support.

Competing Interests: The authors declared that they have no conflict of interests.

Contributors/Acknowledgement: All authors participated equally in designing and estimation of current research.

Views and opinions expressed in this study are the views and opinions of the authors, Asian Journal of Agriculture and Rural Development shall not be responsible or answerable for any loss, damage or liability etc. caused in relation to/arising out of the use of the content.
}

\section{References}

Acharya, S. S., \& Mackey, M. G. A. (2009). Socio-economic impact assessment of the tissue culture banana industry in Kenya. Nairobi: Africa Harvest Biotech Foundation International [Online]. Available from: https://issuu.com/africaharvest/docs/socioeconomic.

Agwara, H. (2017). Highlights of banana market survey [Online]. Available from: https://www.hortinews.co.ke/wp-content/uploads/2017/11/Banana-Producion-andMarket.pdf. 
Bhalerao, N. M., Patil, N. M., Badgujar, C. D., \& Patil, D. R. (2009). Studies on integrated nutrient management for tissue cultured Grand Naine banana. Indian Journal of Agricultural Research., 43, 107-112.

Infonet, B. (2016). Bananas. Infonet Biovision, Nairobi, Kenya [Online]. Available from: http://www.infonet-biovision.org/PlantHealth/Crops/Bananas.

Chillet, M., Castelan, F. P., Abadie, C., Hubert, O., \& Bellaire, L. L. (2013). Necrotic leaf removal, a key component of integrated management of Mycospaerella leaf spot diseases to improve the quality of banana: the case of Sigatoka disease. Fruits, 68(4), 271-277. doi.org/10.1051/fruits/2013073.

Cordeiro, Z. J. M., \& Borges, A. L. (2000). Abiotic cause problems and abnormalities of unknown cause. In: (Ed.): Cordeiro, Z.J.M. Banana. Embrapa-SPI, Brasília. Phytosanitary, p. 8795.

El-Showk, S. (2007). Banana: The history and socio-economics of cultivation [Online]. Available from: http://www.cropdevelopment.org/docs/Banana_History-Impact.pdf.

FAO (2011). Food agricultural organization, the state of the world's land and water resources for food and agriculture (SOLAW). Managing systems at risk. Food and Agriculture Organization of the United Nations, Rome and London, Earth scan [Online]. Available from: http://www.fao.org/docrep/015/i1688e/i1688e00.pdf.

Fageria, N. K., \& Baliger, V. C. (2008). Ameliorating soil acidity of tropical oxisols by liming for sustainable crop production. Advances in Agronomy. 99, 345-399. doi.org/10.1016/s00652113(08)00407-0.

Ganapathi, T., \& Dharmatti, P. R. (2018). Effect of integrated nutrient modules on growth, yield and quality parameters of banana cv. Grand Naine. International Journal of Current $\begin{array}{llll}\text { Microbiology and Aplied } \quad \text { Sciences, } & \text { 7(1), } & \text { 1974-1984. }\end{array}$ doi.org/10.20546/ijcmas.2018.701.239.

Hu, J. M., Fu, H. C., Lin, C. H., Su, H. J., \& Yeh, H. H. (2007). Re-assortment and concerted evolution in banana bunchy top virus genomes. Journal of Virology, 81, 1746-1761. doi.org/10.1128/jvi.01390-06.

Indimuli, R. (2013). Factors influencing the discontinuance in adoption of tissue culture banana technology: a study of smallholder farmers in Maragwa district. Masters Thesis, University of Nairobi.

Isaac, W. P., Brathwaite, R. A. I., \& Ganpat, W. G. (2012). Weed management challenges in Fairtrade banana farm systems in the windward islands of the Caribbean. Herbicides Environmental Impact Studies and Management Approaches, Dr. Ruben AlvarezFernandez (Ed.), ISBN: 978-953-307-892-2 [Online]. Available from: http://cdn.intechweb.org/pdfs/26000.pdf.

Isaac, W. A. P., Brathwaite, R. A. I., Ganpat, W. G., \& Bekele, I. (2007). The impact of selected cover crops on soil fertility, weed and nematode suppression through Farmer Participatory Research by FairTrade banana growers in St. Vincent and the Grenadines. World Journal of Agricultural Sciences, 3(1), 1-9.

Jaetzold, R., Schmidt, H., Hornetz, B., \& Shisanya, C. (2006). Farm management handbook of Kenya. 2nd edition, Volume II: Natural conditions and farm management information. Part C: East Kenya: Ministry of Agriculture/GTZ. Nairobi, Kenya.

James, P. A. (2011). Viruses of banana in East Africa. Doctoral Thesis, Queensland University of Technology.

Kahangi, E. M. (2002). Constraints and sustainable solutions for adoption of TC banana technology and marketing. Acta Horticulturae, 638, 441-447. doi.org/10.17660/actahortic.2004.638.56.

Kasyoka, M. R., Mwangi, M., Mbaka, J., Kori, N., Gitonga, N., \& Muasya, R. (2010). Preferred banana varieties and their seed systems in eastern and central provinces of Kenya. Second RUFORUM Biennial Meeting 20 - 24 September 2010, Entebbe, Uganda [Online]. Available from: https://www.researchgate.net/publication/303460297. 
Kenya Information Guide (2015). Embu County [Online]. Available from: http://www.kenyainformation-guide.com/embu-county.html.

Kirogo, V. (2006). Nutritive value health benefits and selected recipe of sweet potato, Banana. Soya beans and Grain Amaranth: Ministry of Agriculture Livestock and Fisheries, Nairobi, Kenya.

Mbaka, J. N., Mwangi, M., \& Mwangi, M. N. (2008). Banana farming as a business: the role of tissue cultured planting materials in Kenya. Journal of Applied Biosciences, 9(1), 354 361.

Marín, D. H., Romero, R. A., Guzmán, M., \& Sutton, T. B. (2003). Black sigatoka: an increasing threat to banana cultivation. Plant Disease, 87(3), 208-222 [Online]. Available from: https://apsjournals.apsnet.org/doi/pdf/10.1094/PDIS.2003.87.3.208.

Matere, J. S. (2009). Socio-economic factors influencing smallholder banana farmers' participation in banana farmers' association marketing channel in Murang'a south district. Master of Science Thesis, University of Nairobi.

MoALF (2016). Climate risk profile for Embu. Kenya County Climate Risk Profile Series. The Kenya Ministry of Agriculture, Livestock and Fisheries (MoALF), Nairobi, Kenya.

Mugendi, D. N., \& Muriuki, J. (2012). Basic information on soils. In: Mugendi DN. MucheruMuna MW and Mugwe JN (Eds). Soil Fertility: enhancing community extension. P18, 2627. Manilla Publishers, Nairobi, Kenya.

Mugwe, J., Mugendi, D., Muna, M. M., Merckx, R., Chianu, J., \& Vanlauwe, B. (2009). Determinants of the decision to adopt Integrated soil fertility management Practices by smallholder farmers in the Central highlands of Kenya. Experimental Agriculture, 45, 6175. Cambridge University Press. doi:10.1017/S0014479708007072.

Muyanga, M. (2009). Small holder adoption and economic impacts of tissue culture banana in Kenya. African Journal of Biotechnology, 8(23), 6548-6555.

Mwangi, M., \& Nakato, V. (2007). Key factors responsible for the banana xanthomonas wilt pandemic on banana in east and central Africa. Acta Horticulture 828, 395-404. doi.org/10.17660/actahortic.2009.828.41.

Niyongere, C., Ateka, E., Losenge, T., Blomme, G., \& Lepoint, P. (2011). Screening Musa genotypes for Banana Bunchy Top Disease Resistance in Burundi. Proceedings of the International ISHS-ProMusa Symposium on Global Perspectives on Asian Challenges, Acta Horticulture, 997.

Njue, N. I. (2015). Identity, abundance and management of banana Thrips in Embu County, Kenya. Master of Science Thesis, University of Nairobi.

Nguthi, F. N. (2007). Adoption of agricultural innovations by smallholder farmers in the context of HIV/AIDS: The case of tissue-cultured banana in Kenya. Hoogleraar Sociologie van Consumenten en Huishoudens. Wageningen, Wageningen Universiteit. PhD: pp 1-226.

Nyombi, K. (2013). Towards sustainable highland banana production in Uganda: opportunities and challenges. African Journal of Food, Agriculture, Nutrition and Development, 13(2), 7544-7561.

Ouma, G. (2009). Intercropping and its application to banana production in east Africa: a review. Journal of Plant Breeding and Crop Science, 1(2), 13-15.

Ouma, E., Jagwe, J., Obare, G. A., \& Abele, S. (2010). Determinants of smallholder farmers' participation in banana markets in central Africa: the role of transaction costs. Agricultural Economics, 41(2), 111-122. doi:10.1111/j.1574-0862.2009.00429.x.

Pan, M. H., Yuncong, L., \& Malcolm, E. S. (2012). Hand book of soil sciences: resource management and environmental impacts. Second Edition, 24, 29-35, CRC Press London New York.

Queneherve, P., Chabrier, C., Auwerkerken, A., Topart, P., Martiny, B., \& Martie-Luce, S. (2006). Status of weeds as reservoirs of plant parasitic nematodes in banana fields in Martinique. Crop Protection, 25, 860-867. doi.org/10.1016/j.cropro.2005.11.009. 
Rajput, A., Memon, M., Memon, S. K., Tunio, S., Sial, A. T., \& Khan, A. M. (2017). Nutrient composition of banana fruit as affected by farm manure, Composted pressmud and mineral fertilizers. Pakistan Journal Botany, 49(1), 101-108.

Sanginga, N., \& Woomer, P. L. (2009). Integrated soil fertility management in Africa: principles, practices and development process. Tropical Soil Biology and Fertility Institute of the International Centre for Tropical Agriculture. Nairobi.

Shiferaw, B., Hellin, J., \& Muricho, G. (2011). Improving market access and agricultural productivity growth in Africa: what role for producer organizations and collective action institutions?. Food Security, 3(4), 475-489. doi.org/10.1007/s12571-011-0153-0.

Tumuhimbise, R., \& Talengera, D. (2018). Improved Propagation Techniques to Enhance the Productivity of Banana (Musa spp). Open Agriculture, 3(1), 138-145. https://doi.org/10.1515/opag-2018-0014.

Vargas, A., Araya, M., Guzman, M., \& Murillo, G. (2009). Effect of leaf pruning at flower emergence of banana plants (Musa AAA) on fruit yield and black Sigatoka (Mycosphaerella fijiensis) disease. International Journal of Pest Management, 55, 19-25. doi.org/10.1080/09670870802450219.

Wachira, P. M., Kimenju, J. W., Kiarie, J. W., Kihurani, A. W., Mwaniki, S. W., \& Gathaara, V. N. (2013). Incidence of pests and diseases affecting banana in a commercial banana production setting in Kenya. International Journal of Research in Agriculture and Food Sciences, 1, 23-29.

Woniala, J., \& Nyombi, K. (2014). Soil fertility management by smallholder farmers and the impact on soil chemical properties in sironko district, Uganda. Research Journal of Agriculture and Forestry Sciences, 2(1), 5-10.

Wasala, H. O. (2014). Assessing adoption of banana macro-propagation by small-scale farmers in Kisii County. Special Project Report, University of Nairobi [Online]. https://agrieconomics.uonbi.ac.ke/index.php?q=node/1929. 